\title{
Liver X Receptors Regulate Cholesterol Metabolism and Immunity in Hepatic Nonparenchymal Cells
}

\author{
Kaori Endo-Umeda and Makoto Makishima *(D) \\ Division of Biochemistry, Department of Biomedical Sciences, Nihon University School of Medicine, \\ 30-1 Oyaguchi-kamicho, Itabashi-ku, Tokyo 173-8610, Japan; umeda.kaori@nihon-u.ac.jp \\ * Correspondence: makishima.makoto@nihon-u.ac.jp; Tel.: +81-3-3972-8111
}

Received: 15 September 2019; Accepted: 9 October 2019; Published: 11 October 2019

check for updates

\begin{abstract}
Excess dietary cholesterol intake and the dysregulation of cholesterol metabolism are associated with the pathogenesis and progression of nonalcoholic fatty liver disease, nonalcoholic steatohepatitis, and fibrosis. Hepatic accumulation of free cholesterol induces activation of nonparenchymal cells, including Kupffer cells, macrophages, and hepatic stellate cells, which leads to persistent inflammation and fibrosis. The nuclear receptors liver $\mathrm{X}$ receptor $\alpha(\mathrm{LXR} \alpha)$ and LXR $\beta$ act as negative regulators of cholesterol metabolism through the induction of hepatocyte cholesterol catabolism, excretion, and the reverse cholesterol transport pathway. Additionally, LXRs exert an anti-inflammatory effect in immune cell types, such as macrophages. LXR activation suppresses acute hepatic inflammation that is mediated by Kupffer cells/macrophages. Acute liver injury, diet-induced steatohepatitis, and fibrosis are exacerbated by significant hepatic cholesterol accumulation and inflammation in LXR-deficient mice. Therefore, LXRs regulate hepatic lipid metabolism and immunity and they are potential therapeutic targets in the treatment of hepatic inflammation that is associated with cholesterol accumulation.
\end{abstract}

Keywords: cholesterol; liver $\mathrm{X}$ receptor; hepatic nonparenchymal cell; Kupffer cell; macrophage; NAFLD; NASH; hepatic fibrosis

\section{Introduction}

The liver plays an essential role in the metabolism of nutrients, such as proteins, lipids and carbohydrates, and xenobiotics. Biosynthesis, catabolism, and efflux pathways in hepatocytes tightly regulate hepatic cholesterol homeostasis [1], and impaired cholesterol balance can lead to atherosclerosis and nonalcoholic fatty liver disease (NAFLD) [2]. Cholesterol accumulation induces activation of hepatic nonparenchymal cells, including Kupffer cells and stellate cells, and accelerates nonalcoholic steatohepatitis (NASH) and fibrosis. The nuclear receptors liver $\mathrm{X}$ receptor $\alpha(\mathrm{LXR} \alpha$; also called NR1H3) and LXR $\beta$ (NR1H2) are transcription factors that regulate the expression of key genes that are involved in lipid and cholesterol metabolism [3]. LXRs belong to the NR1H nuclear receptor subfamily along with the bile acid receptor farnesoid $X$ receptor (NR1H4) and they are closely related to the NR1I subfamily, which contains vitamin D receptor (NR1I1), pregnane $X$ receptor (NR1I2), and constitutive androstane receptor (NR1I3). These NR1H and NR1I subfamily receptors regulate bile acid metabolism by sensing the metabolic environment [4]. Nuclear receptors have a structure that is comprised of an activation function 1 domain, a DNA-binding domain with a C4-type zinc finger structure, a hinge region, and a ligand-binding domain that contains an activation function 2. Ligand binding induces a conformation change in the receptor, which leads to the dissociation of a corepressor complex and recruitment of a coactivator complex and allows the receptor to induce the transcription of specific target genes. Nuclear receptors, including LXRs, also exhibit transrepression effects. LXRs are also expressed in hepatic nonparenchymal cells, including leukocytes, hepatic stellate cells (HSCs), and liver 
sinusoidal endothelial cells (LSECs), and they regulate immunity and inflammation, contributing to counter-regulation of hepatic inflammation, diet-induced NASH, and fibrosis. Thus, LXRs play important roles in both hepatocytes and nonparenchymal cells. The liver plays important roles in both lipid metabolism and innate immunity as a gateway for dietary signals, and LXRs are suggested to have a gatekeeper function in the liver. Although synthetic LXR agonists have been developed, their clinical application is limited by adverse effects, such as hypertriglyceridemia and neuropsychiatric symptoms $[5,6]$. Function-selective LXR agonists might have promising therapeutic potential for liver diseases by regulating lipid metabolism and immune responses. Here, we review the role of LXRs in hepatic nonparenchymal cell function and the pathogenesis of liver diseases.

\section{Hepatic Nonparenchymal Cells}

A variety of cell types are present in the liver: $70-80 \%$ are parenchymal cells, hepatocytes, and cholangiocytes, and 20-30\% are nonparenchymal cells, including leukocytes, HSCs, and LSECs $[7,8]$. As the liver samples bacterial components and xenobiotics, together with nutrients, from the portal vein, immune cells are present and have a patrolling function in the sinusoids. Hepatic immune cells principally consists of resident Kupffer cells, bone marrow-derived macrophages (BMDMs), natural killer (NK) cells, natural killer T (NKT) cells, T cells, and B cells. These cells play essential roles in the regulation of metabolism, host defense, anti-tumor immunity, and regeneration as a functional network in combination with hepatocytes [9].

\subsection{Two Types of Macrophages: Resident Kupffer Cells and Bone Marrow-Derived Macrophages (BMDMs)}

In the steady-state condition, there are two types of macrophages in mouse liver: resident Kupffer cells and BMDMs. Fate mapping studies show that resident Kupffer cells originate from erythro-myeloid progenitor cells expressing Csf1 $r$, which encodes the gene for colony stimulating factor 1 receptor, in the yolk sac, and they are maintained in the fetal liver independent from hematopoietic stem cells $[10,11]$. On the other hands, BMDMs differentiate and develop from monocytes that originate from bone marrow. It has also been shown that there are at least two kinds of macrophages with different transcriptome profiles that are present in normal human liver [12,13]. Cell surface markers, distribution, and function differ between Kupffer cells and BMDMs [14]. Kupffer cells are radioresistant, show a F4/80hi CD11b phenotype, are present in the midzonal area, and have strong capacity for phagocytosis and reactive oxygen species production [15-17]. By contrast, BMDMs are radiosensitive, show F4/80 ${ }^{\mathrm{lo}} \mathrm{CD} 11 \mathrm{~b}^{+}$, are present in the periportal area, and have higher capacity to produce pro-inflammatory cytokines and promote liver regeneration. Pro-inflammatory signals, including toll-like receptor (TLR) ligands, induce the migration and activation of BMDMs through a mechanism that requires $\mathrm{C}-\mathrm{C}$ chemokine 2 and its receptor C-C chemokine receptor $2[18,19]$. Interestingly, detailed characterization of mouse liver $\mathrm{CD} 45^{+}$leukocytes using CyTOF mass cytometry has identified two kinds of Kupffer

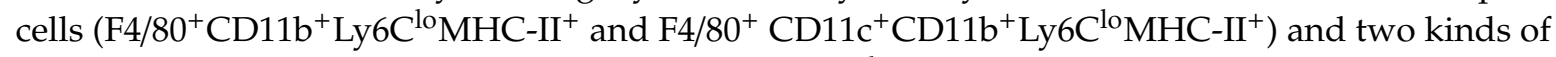
infiltrating monocytes $\left(\mathrm{F} 4 / 80^{+} \mathrm{Ly}_{6 \mathrm{C}^{+}}\right.$and $\left.\mathrm{F} 4 / 80^{-} \mathrm{CD} 11 \mathrm{c}^{\mathrm{lo}} \mathrm{Ly} 6 \mathrm{C}^{+}\right)$[20]. Additionally, a recent report utilizing single-cell RNA sequencing analysis demonstrates that three kinds of BMDMs can be detected and that their populations are changed by western-type diet feeding [21]. Western diet feeding decreases the expression of S100a8 and S100a9 in monocytes, macrophages, and dendritic cells in the liver, which suggests a reduced inflammatory capacity of BMDMs during NAFLD progression, a compensatory mechanism to limit local inflammation. Triggered receptor expressed on myeloid cells 2 (TREM2), a lipid-sensing surface receptor that belongs to the immunoglobulin superfamily, is expressed in myeloid cells, such as microglia, dendritic cells, and osteoclasts, and regulates the development and function of these cells [22]. TREM2 interacts with the adaptor protein DNAX activation protein of $12 \mathrm{kDa}$, called DAP12, and recruits the Syk tyrosine kinase for signal transmission in cells. TREM2 plays a protective role in mouse models of Alzheimer disease [23], and TREM2 variants are associated with an increased risk of Alzheimer disease [24,25]. LXR agonist treatment stimulates microglial phagocytosis with the induction of the phagocytic receptors Axl and Mer receptor tyrosine kinase 
(MerTK) [26]. MerTK ${ }^{+} / \mathrm{Axl}^{+}$macrophages surrounding plaques in mouse models of Alzheimer disease express TREM2. The Mertk gene is an LXR direct target [27]. TREM2 ${ }^{\text {hi }}$ macrophages, which reveal enriched Trem 2 mRNA expression, are specifically detected in atherosclerotic aortas in murine models, and TREM2 protein expression is increased in macrophages in human atherosclerotic lesions [28]. Trem2-expressing macrophages appear in obese adipose tissue and the genetic deletion of Trem 2 in mice leads to adipocyte hypertrophy, hypercholesterolemia, and glucose intolerance [29]. The Trem 2 gene is highly expressed in Kupffer cells from diet-induced NASH mouse livers and TREM2 mRNA levels are increased in livers from patients with hepatic steatosis and NASH [30]. The population and function of resident macrophages, including Kupffer cells, and BMDMs, may be dynamically altered by the context of signals and environmental changes to regulate and be involved in metabolic regulation as well as immunity.

\subsection{Hepatic Stellate Cells (HSCs)}

HSCs are mesenchymal cells that are present in the endothelial space of Disse and they are responsible for the promotion of hepatic fibrosis. In quiescent conditions, HSCs contain abundant lipid droplets of retinyl esters. When HSCs are activated by soluble factors including transforming growth factor $\beta$ and platelet-derived growth factor, these cells transdifferentiate to myofibroblasts, a process that is marked by S100A6 expression, depletion of stored lipids, enhanced proliferation, and fibrogenic action mediated by the induction of $\alpha$-smooth muscle actin ( $\alpha$-SMA) and collagen $\alpha 1$ (I) (Col1a1) [31]. The activity and survival of HSCs are strongly influenced by macrophages, granulocytes, and lymphocytes, and the interaction between HSCs and induced hepatic immune cells contributes to hepatic fibrosis [32].

\subsection{Liver Sinusoidal Endothelial Cells (LSECS)}

LSECs are abundantly present in the liver sinusoid and they play a role in the progression of NAFLD, fibrosis, and hepatocellular carcinoma (HCC) [33]. Unlike endothelial cells in other tissues, LSECs are composed of pores, called fenestrae, and transfer macromolecules, such as chylomicron remnants, between blood and the space of Disse for efficient uptake by hepatocytes. LSECs have strong endocytic activity and they maintain a quiescent HSC phenotype. In pathological conditions, such as chronic liver injury, LSECs are capillarized, lose fenestrae, and allow for HSCs to activate fibrotic action [34].

\subsection{Natural Killer (NK) Cells and Natural Killer T (NKT) Cells}

The innate immune leukocytes NK cells and NKT cells are abundantly present in the rodent liver in physiological conditions. NKT cells are a semi-variant of $\mathrm{T}$ cells that express markers of both NK cells (NK1.1) and conventional T cells ( $\alpha \beta-\mathrm{T}$ cell receptor). NKT cells are activated by specific glycolipid antigens, such as $\alpha$-galactosylceramide ( $\alpha$-GalCer), presented to the MHC class I-like CD1d molecule in antigen-presenting cells [35]. After thymic maturation and development, peripheral NKT cells express an invariant $\mathrm{T}$ cell receptor $(\mathrm{V} \alpha 14-\mathrm{J} \alpha 18$ and $\mathrm{V} \beta 8.2, \mathrm{~V} \beta 7$ or $\mathrm{V} \beta 2$ in mouse and $\mathrm{V} \alpha 24-\mathrm{J} \alpha 18$ and V $\beta 11$ in human) and produce both the Th1 cytokine interferon- $\gamma$ and the Th2 cytokine interleukin (IL)-4 [36]. Hepatic invariant NKT (iNKT) cells have multiple functions, such as mediating acute inflammation [37], anti-tumor immunity in cooperation with NK cells [38,39], regeneration [40], and tissue repair [41]. HSECs, which express C-X-C motif ligand 16, are involved in the recruitment of cells positive for C-X-C motif chemokine receptor 6 (CXCR6), particularly NKT cells, in the liver [42]. CXCR6 deletion in mice decreases the intrahepatic numbers of iNKT cells and $\mathrm{CD}^{+}$cells and enhances diethylnitrosamine-induced hepatocarcinogenesis [43]. Analysis of human samples reveals that CXCR6 expression is increased in cirrhotic livers but decreased in HCC [43]. 


\section{Cholesterol Metabolism and Function of Hepatic Nonparenchymal Cells in Liver Diseases}

\subsection{NAFLD and NASH in Hypercholesterolemic Mice}

Cholesterol accumulation in macrophages triggers inflammatory responses that are mediated by TLR signaling and inflammasome activation, and enhances further immune cell recruitment from bone marrow [44]. High cholesterol diet (HCD) or a western-style diet containing high-fat and high-cholesterol diet (HFCD) induces free cholesterol accumulation in hepatocytes and causes NAFLD, $\mathrm{NASH}$, and hepatic fibrosis in mice [45]. Inflammasome activation that is induced by cholesterol crystals is also involved in the progression of NASH [46]. Treatment with statins decreases hepatic free cholesterol content and ameliorates the NASH phenotype in mice that were fed HCD or HFCD [45]. Under lipid-enriched conditions, hepatocytes influence the population and activation of several nonparenchymal cells. Among the immune cells, F4/80 ${ }^{\mathrm{lo}} \mathrm{CD} 11 \mathrm{~b}^{+}$BMDMs rather than F4/80 ${ }^{\text {hi }} \mathrm{CD}^{-} \mathrm{Bb}^{-}$ resident Kupffer cells are significantly increased in HCD- and HFCD-fed mice, not in high-fat diet (HFD)-fed mice [47]. The relative population of BMDMs to resident Kupffer cells is increased in a cholesterol-dose dependent manner [48]. There are distinct gene expression profiles in resident Kupffer cells and BMDMs in HCD-fed mice. While resident Kupffer cells express genes that are involved in lipid metabolism, tissue repair, and regeneration, BMDMs highly express pro-inflammatory cytokines and chemokines, which promotes further inflammation.

\subsection{Acute Hepatic Inflammation}

HCD- or HFCD-fed mice are susceptible to stimulation with TLR ligands, such as Escherichia coli, lipopolysaccharide (LPS), and CpG oligonucleotide, which are associated with strong pro-inflammatory cytokine production, acute liver injury, and increased numbers and activation of $F 4 / 80^{\mathrm{lo}} \mathrm{CD} 11 \mathrm{~b}^{+}$ BMDMs [47,49].

\subsection{Hepatic Fibrosis and Hepatocellular Carcinoma (HCC)}

Cholesterol feeding increases free cholesterol accumulation in HSCs as well as hepatocytes. Accumulated cholesterol esters are hydrolyzed to free cholesterol by lysosomal acid lipase, which likely results in cholesterol crystallization $[1,50]$. Cholesterol crystals are highly proinflammatory and the presence of cholesterol crystals is associated with the development of fibrosing NASH in humans [50]. In a fibrosis model with bile duct ligation (BDL) or carbon tetrachloride $\left(\mathrm{CCl}_{4}\right)$ treatment, $\mathrm{HCD}$ feeding enhances the hepatic gene expression of Acta2 (the gene encoding $\alpha$-SMA) and Col1a1 (the gene encoding collagen $\alpha 1(\mathrm{I}))$ [51]. $\alpha$-SMA and collagen $\alpha 1(\mathrm{I})$ are specific markers of activated stellate cells [52]. Interestingly, HCD feeding does not affect hepatocyte damage, macrophage infiltration, or pro-inflammatory gene expression induced by BDL or $\mathrm{CCl}_{4}$ treatment. In addition, BDL or $\mathrm{CCl}_{4}$-induced liver fibrosis is exacerbated in mice lacking acyl-coenzyme A:cholesterol acyltransferase 1 , which indicates that free cholesterol accumulation enhances the progression of fibrosis [53]. Increased fibrosis also enhances the development of HCC in long-term $\mathrm{CCl}_{4}$-treated, HFCD-fed mice [54]. Thus, excess free cholesterol in HSCs rather than in parenchyma or myeloid cells is strongly involved in the progression of liver fibrosis.

\subsection{Anti-Tumor Immunity}

Hepatic cholesterol accumulation activates not only myeloid cells and HSCs, but also lymphocytes, such as NK cells and NKT cells. In HCD- or HFCD-fed mice, the number of NK cells are increased along with expression of activation marker CD69 [47]. HCD or HFCD feeding increases the sensitivity of mice to $\alpha$-GalCer treatment, which indicates that NK cells and NKT cells are also activated in HCD-fed mice [49]. Cytotoxic activity against tumor cells is enhanced in hepatic mononuclear cells (MNCs) that are isolated from HFCD-fed mice, and stimulation with LPS or IL-12 improves the survival of HFCD-fed mice in a tumor metastasis model [47]. 


\section{Oxysterol Receptors $\operatorname{LXR} \alpha$ and $\operatorname{LXR} \beta$}

\subsection{Regulation of Lipid Metabolism}

$\mathrm{LXR} \alpha$ and LXR $\beta$ belong to the nuclear receptor superfamily and function as ligand-dependent transcription factors [3]. LXR $\alpha$ is highly expressed in metabolic organs, such as liver (hepatocytes), adipose tissues, kidney, and macrophages, whereas LXR $\beta$ is present ubiquitously. LXRs are activated by oxysterols, such as 24(S),25-epoxycholesterol, 20(S)-hydroxycholesterol, 22(R)-hydroxycholesterol, 24(S)-hydroxycholesterol, $7 \alpha$-hydroxycholesterol, 25-hydroxycholesterol, and 27-hydroxycholesterol [55-57], and regulate the expression of genes that are involved in lipid metabolism and immunity [3]. Phytosterols and 7-dehydrocholesterol metabolites can act as LXR ligands [58,59]. LXRs preferentially bind to a DNA element that consists of a two-hexanucleotide (AGGTCA or a related sequence) direct repeat motif that is separated by four nucleotides, called the direct repeat 4 , as a heterodimer with retinoid X receptor (RXR). Although RXR-LXR $\alpha$ and RXR-LXR $\beta$ heterodimers function as permissive heterodimers, in that they can be activated by both LXR and RXR ligands, the physiological role of RXR signaling in the heterodimers remains elusive. LXRs play a central role in the regulation of cholesterol homeostasis. In rodent hepatocytes, oxysterols, which are increased with excess cholesterol, activate LXR $\alpha$ and stimulate the catabolism of cholesterol to bile acid by inducing the expression of the rate-limiting enzyme in the bile acid synthetic pathway, cholesterol $7 \alpha$-hydroxylase [60]. Hepatocyte LXR $\alpha$ also increases the expression of ATP-binding cassette (ABC) transporter G5 and ABCG8, and it stimulates biliary cholesterol excretion [61]. LXR $\alpha$-deficient mice that were fed HCD show severe cholesterol accumulation in the liver [60]. In macrophages, LXRs induce the expression of ABCA1 and apolipoprotein E and stimulate reverse cholesterol transport [62,63]. Therefore, LXR agonist treatment suppresses the development of atherosclerosis in a mouse model [64]. Although hepatocyte-specific LXR $\alpha$ knockout mice show a dysregulation of hepatic cholesterol metabolism and accelerated atherogenesis, LXR agonist treatment still has an atheroprotective effect [65]. Bone marrow transplantation of $L X R \alpha / \beta$-deficient cells to atherogenic mice increases atherosclerotic lesions in the aorta [66]. Therefore, both liver and macrophage LXRs are required for whole body cholesterol homeostasis and protection against atherosclerosis.

\subsection{Anti-Inflammatory Function in Immune Cells}

LXR agonist treatment suppresses the expression of pro-inflammatory genes, such as inducible nitric oxide synthase and cyclooxygenase-2, as induced by the TLR4 ligand LPS in mouse peritoneal macrophages by inhibiting corepressor protein dissociation from the inflammatory transcription factor nuclear factor $\mathrm{kB}$ [67-69]. LXR activation also represses TLR ligand-dependent inflammatory effects in an ABCA1-dependent manner, and it directly modulates chromatin accessibility in pro-inflammatory gene enhancers through a cis-repressive interaction [70,71]. In atherosclerotic mice, cholesterol accumulation in macrophages induces the production of desmosterol, which acts as an LXR ligand and regulates lipid metabolism and inflammation [72]. Genome-wide analysis shows that LXR $\alpha$ and LXR $\beta$ regulate transcription programs in both common and distinct mechanisms [73]. LXR $\alpha$ preferentially regulates the expression of genes that are related to lipid metabolism, apoptosis, inflammation, and immune cell migration, while LXR $\beta$ is involved in lymphocyte differentiation. Both LXRs are involved in the regulation of genes for DNA replication and rRNA processing. LXR also regulates immune cell migration by an indirect mechanism through chemotactic signaling in dendritic cells [74]. LXR activation enhances dendritic cell chemotaxis dependent on CCL19 and CCL21 by inducing the expression of CD38, which is involved in leukocyte trafficking and is associated with atherosclerosis. In contrast, tumor cells produce LXR ligands, which suppress CCR7 expression in dendritic cells and attenuate antitumor immunity [75].

$\mathrm{CD}^{+} \mathrm{T}$ cells can differentiate into Tc1, Tc2, Tc9, and Tc17 cells under various cytokine conditions, and LXR activation by cholesterol accumulation inhibits the expression of IL-9, which is indispensable for Tc9 cell persistence and antitumor effects [76]. Interestingly, the pharmacological activation of 
LXR reduces myeloid-derived suppressor cell abundance in murine models and in human cancer patients [77]. LXR activation increases the expression of apolipoprotein E, which induces apoptosis of myeloid-derived suppressor cells, leading to the activation of cytotoxic $\mathrm{T}$ cells and effective anti-tumor responses. Furthermore, LXR ligand treatment suppresses Th1 and Th17 polarization and induces Treg differentiation [78]. Thus, LXRs control immune cell function through direct and indirect mechanisms.

\section{LXR Function in Hepatic Nonparenchymal Cells in Liver Diseases}

\subsection{Expression of LXRs in Liver Nonparenchymal Cells}

LXR $\alpha$ is highly expressed in rat resident Kupffer cells [79]. In mouse liver, LXR $\alpha$ and LXR $\beta$ are both abundantly present in hepatic MNCs, and LXR $\alpha$ is preferentially expressed in F4/80hi CD $11 b^{\text {lo }}$ Kupffer cells rather than $\mathrm{F} 4 / 80^{\mathrm{lo}} \mathrm{CD} 11 \mathrm{~b}^{+}$BMDMs [80]. Clec4f encodes C-type lectin domain family 4 member F, which is a glycosylated membrane protein that is co-expressed with F4/80 on Kupffer cells and it interacts with $\alpha$-GalCer [81]. A genome-wide study shows that the specific expression of $\mathrm{LXR} \alpha$ is observed together with Clec4f expression in resident Kupffer cells and that LXR-regulating sequence motifs are enriched in the Kupffer cell-specific enhancer region [82]. The transcription factor zinc finger E box binding homeobox 2, which is known to play a role in epithelial to mesenchymal transition, controls LXR $\alpha$ expression to maintain the tissue-specific phenotype in resident Kupffer cells [83]. Thus, LXRs, specifically $\mathrm{LXR} \alpha$, are functionally expressed not only in hepatocytes, but also in nonparenchymal cells, including resident Kupffer cells in the physiological condition. The effects of LXR activation or deletion in nonparenchymal cells are summarized (Table 1).

Table 1. Effects of liver X receptor (LXR) activation or deletion in hepatic nonparenchymal cells in animal models of liver disease.

\begin{tabular}{|c|c|c|c|c|c|c|}
\hline Animal & LXR & $\begin{array}{l}\text { Acute or } \\
\text { Chronic }\end{array}$ & Treatment & Target Cells & Findings & Ref \\
\hline $\begin{array}{l}\text { Mouse (WT, } \\
\mathrm{LXR} \alpha / \beta-\mathrm{KO})\end{array}$ & Absence & & No treatment & $\begin{array}{c}\mathrm{F} 4 / 80^{\mathrm{lo}} \mathrm{CD} 11 \mathrm{~b}^{+} \\
\text {Kupffer } \\
\text { cells/macrophages }\end{array}$ & $\begin{array}{c}\mathrm{F} 4 / 80^{\mathrm{lo}} \mathrm{CD} 11 \mathrm{~b}^{+} \text {cells } \uparrow \\
\text { Inflammatory gene } \\
\text { expression in hepatic } \\
\text { MNCs } \uparrow\end{array}$ & [80] \\
\hline Rat (WT) & Activation & Acute & $\begin{array}{c}\text { GW3965 }(0.1 \text { or } \\
0.3 \mathrm{mg} / \mathrm{kg}) \\
\text { LPS }(5 \mathrm{mg} / \mathrm{kg}) / \\
\text { Peptidoglycan } \\
(1 \mathrm{mg} / \mathrm{kg}) \text { for } 1-6 \mathrm{~h}\end{array}$ & $\begin{array}{c}\text { Kupffer } \\
\text { cells/macrophages }\end{array}$ & $\begin{array}{c}\text { Plasma TNF- } \alpha, \text { PGE2, } \\
\text { ALT, bilirubin } \downarrow \\
\text { Hepatocyte injury } \downarrow\end{array}$ & {$[79,84]$} \\
\hline Mouse (WT) & Activation & Acute & $\begin{array}{c}\text { HFD (8 weeks), } \\
\text { T0901317 (30 mg/kg } \\
\text { for } 7 \text { days) } \\
\text { LPS (50 } \mu \mathrm{g} / \text { mouse) }\end{array}$ & $\begin{array}{c}\text { Kupffer } \\
\text { cells/macrophages }\end{array}$ & $\begin{array}{c}\text { Plasma AST/ALT } \downarrow \\
\text { Hepatic TNF- } \alpha, \text { iNOS } \\
\text { expression } \downarrow \\
\text { Hepatic PI3K, NF- } \kappa B \text {, } \\
\text { MAPK signaling } \downarrow\end{array}$ & [85] \\
\hline Mouse (WT) & Activation & Acute & $\begin{array}{c}\text { T0901317 }(50 \mathrm{mg} / \mathrm{kg} \\
\text { for } 12 \mathrm{~h}) \\
\text { LPS }(10 \mathrm{mg} / \mathrm{kg} \text { for } \\
12 \mathrm{~h})\end{array}$ & $\begin{array}{c}\text { Kupffer } \\
\text { cells/macrophages }\end{array}$ & $\begin{array}{c}\text { Leukocyte infiltration } \downarrow \\
\text { Plasma AST/ALT } \downarrow \\
\text { Plasma, supernatant of } \\
\text { Kupffer cells TNF- } \alpha \text {, } \\
\text { IFN- } \beta, \text { IL- } 1 \beta \downarrow, \text { IL- } 10 \uparrow\end{array}$ & [86] \\
\hline $\begin{array}{l}\text { Mouse (WT, } \\
\text { LXR } \alpha-K O)\end{array}$ & Absence & $\begin{array}{l}\text { Chronic } \\
\text { (NASH) }\end{array}$ & HFCD (4 weeks) & $\begin{array}{c}\text { Kupffer } \\
\text { cells/macrophages } \\
\text { iNKT cells }\end{array}$ & $\begin{array}{c}\mathrm{F} 4 / 80^{+} \mathrm{CD} 68^{+} \mathrm{CD} 11 \mathrm{~b}^{+} \\
\text {cells } \uparrow \\
\text { iNKT cells } \downarrow \\
\text { Plasma AST/ALT } \uparrow\end{array}$ & [87] \\
\hline $\begin{array}{l}\text { Mouse (WT, } \\
\text { LXR } \alpha-\mathrm{KO})\end{array}$ & Absence & $\begin{array}{l}\text { Chronic } \\
\text { (NASH) }\end{array}$ & $\begin{array}{c}\text { HFCD (4 weeks) } \\
\text { LPS }(2.5 \mathrm{mg} / \mathrm{kg}, 1-6 \mathrm{~h})\end{array}$ & $\begin{array}{c}\text { Kupffer } \\
\text { cells/macrophages }\end{array}$ & $\begin{array}{c}\text { Leukocyte } \\
\text { accumulation } \uparrow \\
\text { Plasma TNF- } \alpha \text {, IFN- } \gamma \text {, } \\
\text { IL-12, CCL2, AST/ALT } \uparrow\end{array}$ & [87] \\
\hline $\begin{array}{l}\text { Mouse (WT, } \\
\text { LXR } \alpha-K O)\end{array}$ & Absence & $\begin{array}{l}\text { Chronic } \\
\text { (NASH) }\end{array}$ & $\begin{array}{c}\text { HFCD (4 weeks) } \\
\alpha \text {-GalCer, } 0.1 \mathrm{mg} / \mathrm{kg}, \\
1-72 \mathrm{~h})\end{array}$ & iNKT cells & Plasma IL-4, IFN- $\gamma \downarrow$ & [87] \\
\hline $\begin{array}{l}\text { Mouse (WT, } \\
\text { LXR } \alpha-K O)\end{array}$ & Absence & $\begin{array}{l}\text { Chronic } \\
\text { (NASH) }\end{array}$ & $\begin{array}{l}\text { HFCD (4 weeks) } \\
\text { Con-A, } 12.5 \mathrm{mg} / \mathrm{kg} \text {, } \\
1-72 \mathrm{~h})\end{array}$ & iNKT cells & $\begin{array}{c}\text { Plasma AST/ALT, } \\
\text { bilirubin } \downarrow \\
\text { Hepatocyte necrosis } \downarrow\end{array}$ & [87] \\
\hline
\end{tabular}


Table 1. Cont.

\begin{tabular}{|c|c|c|c|c|c|c|}
\hline Animal & LXR & $\begin{array}{l}\text { Acute or } \\
\text { Chronic }\end{array}$ & Treatment & Target Cells & Findings & Ref \\
\hline $\begin{array}{l}\text { Mouse }(W T \\
L X R \alpha / \beta-K O)\end{array}$ & Absence & $\begin{array}{l}\text { Chronic } \\
\text { (Fibrosis) }\end{array}$ & $\begin{array}{c}\mathrm{CCl}_{4}(10 \%, v / v, \text { twice } \\
\text { per week for } 4 \text { weeks })\end{array}$ & HSCs & $\begin{array}{c}\text { Plasma ALT } \uparrow \\
\text { Col1a1 expression } \uparrow \\
\text { Fibrosis } \uparrow\end{array}$ & [88] \\
\hline $\begin{array}{l}\text { Mouse }(W T \\
\mathrm{LXR} \alpha / \beta-\mathrm{KO})\end{array}$ & Absence & $\begin{array}{l}\text { Chronic } \\
\text { (Fibrosis) }\end{array}$ & $\begin{array}{l}\text { Methionine/choline-deficient } \\
\text { diet (1 month) }\end{array}$ & HSCs & $\begin{array}{c}\text { Col1a1 expression } \uparrow \\
\text { Fibrosis } \uparrow\end{array}$ & [88] \\
\hline Mouse (WT) & Activation & $\begin{array}{l}\text { Chronic } \\
\text { (Fibrosis) }\end{array}$ & $\begin{array}{c}\text { T0901317 }(50 \mathrm{mg} / \mathrm{kg}, \\
\text { daily for } 1 \text { week }) \\
\mathrm{CCl}_{4}(10 \%, v / v, \text { twice } \\
\text { per week for } 1 \text { month })\end{array}$ & LSECs & $\begin{array}{c}\text { CD31 }^{+} \text {LSEC } \\
\text { capillarization } \downarrow \\
\text { Hepatic F4/80 cells } \downarrow \\
\text { Fibrotic score } \downarrow\end{array}$ & [89] \\
\hline $\begin{array}{l}\text { Mouse (WT, } \\
\text { LXR } \alpha-K O)\end{array}$ & Absence & $\begin{array}{l}\text { Chronic } \\
\text { (Fibrosis) }\end{array}$ & $\begin{array}{l}\mathrm{CCl}_{4}(10 \%, v / v \text {, twice } \\
\text { per week for } 1 \text { month })\end{array}$ & LSECs & $\begin{array}{c}\text { CD31 }^{+} \text {LSEC } \\
\text { capillarization } \uparrow \\
\text { Hepatic F4/80 } / 80^{+} \text {cells } \uparrow \\
\text { Fibrotic score } \uparrow\end{array}$ & [89] \\
\hline $\begin{array}{c}\text { Mouse } \\
(A t p 7 b-\mathrm{KO})\end{array}$ & Activation & $\begin{array}{l}\text { Chronic } \\
\text { (Wilson } \\
\text { disease) }\end{array}$ & $\begin{array}{l}\text { T0901317 }(50 \mathrm{mg} / \mathrm{kg} \text {, } \\
\text { thrice per week for } \\
\text { 8 weeks })\end{array}$ & $\begin{array}{l}\text { Kupffer } \\
\text { lls/macrophages } \\
\text { HSCs }\end{array}$ & $\begin{array}{c}\text { Hepatic inflammatory } \\
\text { or fibrotic genes } \downarrow \\
\text { Plasma AST/ALT } \downarrow\end{array}$ & [90] \\
\hline
\end{tabular}

Arrows indicate as follows: $\uparrow$, increase; $\downarrow$, decrease.

\subsection{Acute Hepatic Inflammation}

Anti-inflammatory effects of LXR agonist are observed in rodent liver Kupffer cells and MNCs as well as in BMDMs or peritoneal macrophages. In cultured Kupffer cells, LXR agonist treatment suppresses tumor necrosis factor (TNF)- $\alpha$ production that is induced by LPS [79,91]. LXR ligand treatment decreases plasma pro-inflammatory cytokine production, ALT levels, and leukocyte infiltration in LPS-challenged rats and mice $[79,84,86]$. LXR ligand treatment also attenuates LPS-induced transaminitis, TNF- $\alpha$, and inducible nitric oxide synthase expression in HFD-fed mice [85], and inhibits pro-inflammatory cytokine expression in cultured mouse hepatic MNCs [80]. TLR ligand-stimulated pro-inflammatory gene expression is strongly enhanced in cultured hepatic MNCs from LXR $\alpha / \beta$-knockout mice, and LPS administration induces severe hepatocyte damage in LXR $\alpha / \beta$-knockout mice [80] (Figure 1). LXR $\alpha / \beta$-knockout mice, but not LXR $\alpha$ - or LXR $\beta$-knockout mice, show an increased number of liver $\mathrm{F} 4 / 80^{\mathrm{lo}} \mathrm{CD} 11 \mathrm{~b}^{+}$BMDMs and a higher expression of $\mathrm{Ccl} 2$. CCL2 from hepatocytes recruits myeloid cells expressing its receptor, $\mathrm{C}-\mathrm{C}$ chemokine receptor 2 , to the liver [92]. Therefore, $L X R \alpha$ and LXR $\beta$ are both involved in the suppression of acute liver injury by regulating pro-inflammatory gene expression and the recruitment of BMDMs.

\subsection{Effects of LXR Activation or Absence in NAFLD and NASH}

Despite the beneficial effects on cholesterol metabolism and the inhibition of inflammation, LXR agonist stimulates lipogenesis and induces hepatic steatosis by increasing the expression of sterol regulatory element-binding protein-1c, fatty acid synthase, and stearoyl-CoA desaturase [93,94]. Interestingly, the LXR endogenous ligand 27-hydroxycholesterol suppresses HFD-induced steatohepatitis by decreasing leukocyte recruitment and pro-inflammatory gene induction in Kupffer cells without affecting hepatic sterol regulatory element-binding protein-1c expression [95]. A recent study shows that the production of some specific oxysterols, such as 24(S)-hydroxycholesterol and 7 $\beta$-hydroxycholesterol, is increased in the liver of NASH model mice and human patients [5]. Oxysterols might be involved in the pathogenesis of NAFLD/NASH independently from LXR activation, and the role of LXR signaling as oxysterol receptors in the development of NAFLD/NASH remains to be elucidated.

LXR $\alpha$ deletion, not LXR $\beta$ deletion, results in increased hepatic cholesterol content, liver weight, and plasma transaminase levels in HCD-fed mice $[6,60]$. The population of $\mathrm{F} 4 / 80^{+} \mathrm{CD} 68^{+} \mathrm{CD} 11 \mathrm{~b}^{+}$ macrophages is increased in $\mathrm{LXR} \alpha$-knockout mice fed HFCD for four weeks, associated with hepatic cholesterol accumulation [87] (Figure 2). LPS challenge in these mice induces more severe hepatic damage. Interestingly, although the expression of the lymphocyte activation marker CD69 is increased in NK cells, the number of iNKT cells is decreased, and the response to the NKT activator $\alpha$-GalCer is 
impaired in these mice. Increased cell number and activation of Kupffer cells by lipid overload induces NKT cell death in mouse liver [96]. Choline-deficient diet feeding activates Kupffer cells and increases IL-12 production, which leads to the depletion of NKT cells [97]. The absence of LXR $\alpha$ function induces cholesterol accumulation in hepatocytes, activates Kupffer cells/macrophages, and decreases iNKT cells. A mechanistic understanding of the contribution of LXRs in the regulation of hepatic iNKT cells remains incomplete.

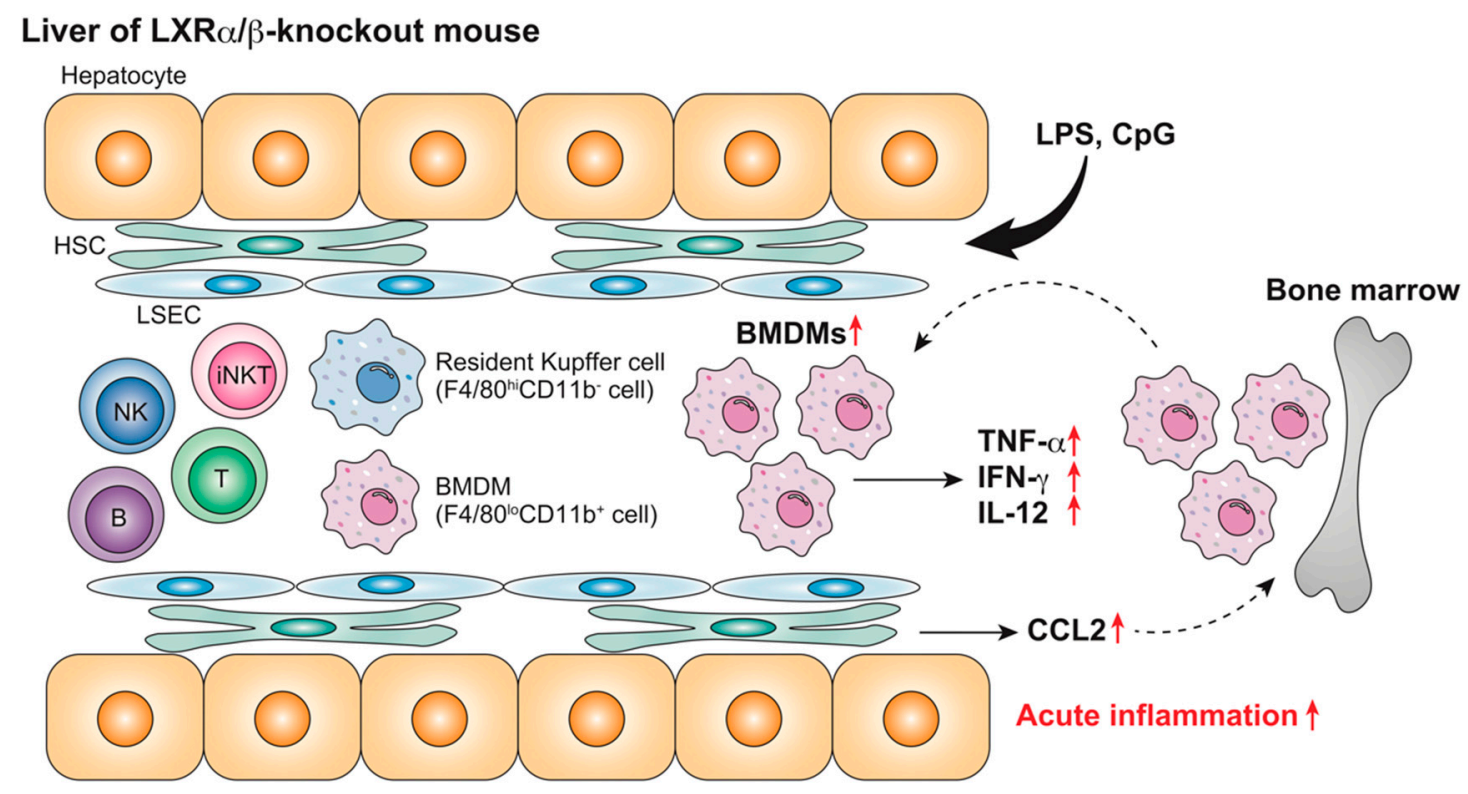

Figure 1. Acute hepatic inflammation in $\mathrm{LXR} \alpha / \beta$-knockout mice. Lipopolysaccharide (LPS) administration stimulates inflammatory cytokine production and recruitment of $\mathrm{F} 4 / 80^{\mathrm{lo}} \mathrm{CD} 11 \mathrm{~b}^{+}$bone marrow-derived macrophages (BMDMs) in the liver of $L X R \alpha / \beta$-knockout mice more effectively than in wild-type mice [80]. LXRs regulate acute hepatic inflammatory responses. $\uparrow$, increase.

\section{Liver of LXR $\alpha$-knockout mouse}

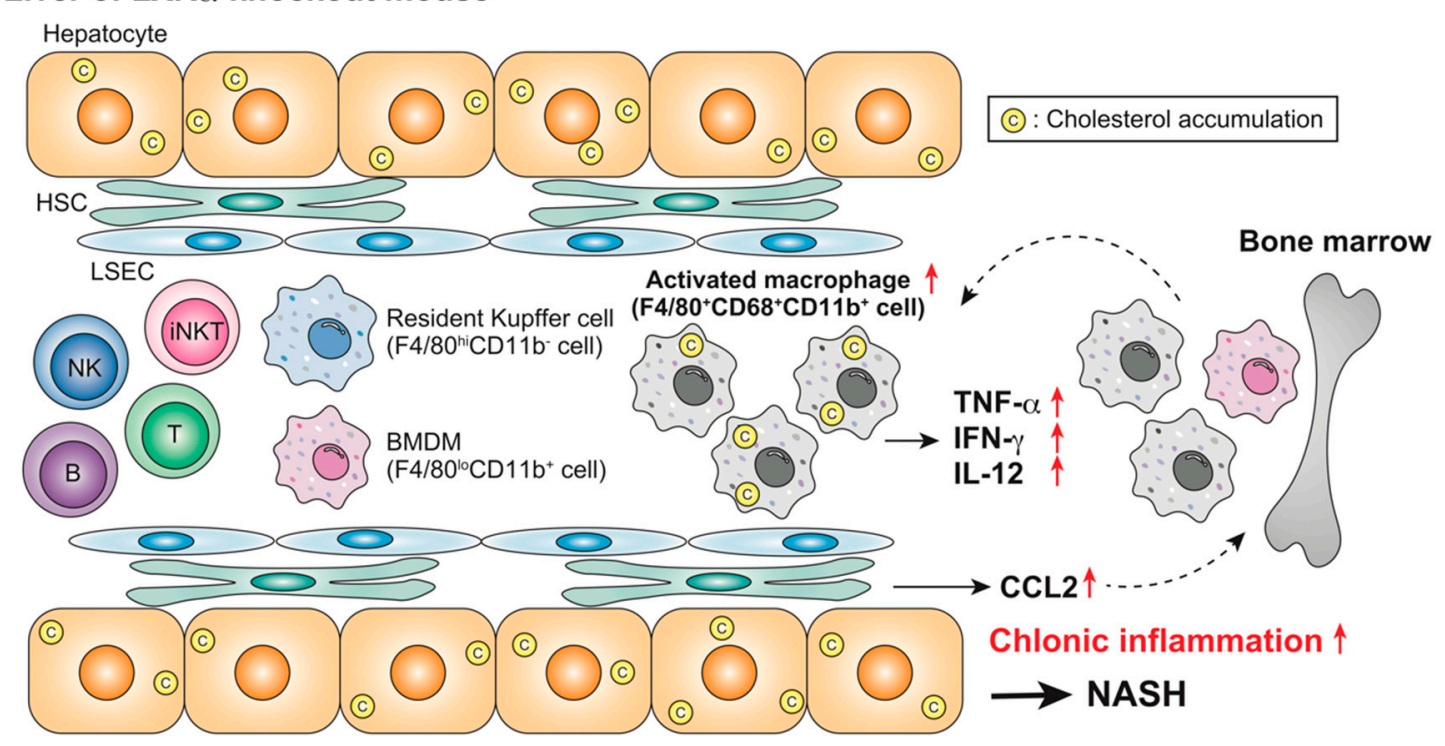

Figure 2. Nonalcoholic steatohepatitis (NASH) in high-cholesterol diet (HFCD)-fed LXR $\alpha$-knockout mice. HFCD feeding induces severe steatohepatitis in LXR $\alpha$-knockout mice, associated with an increase in $\mathrm{CD} 68^{+} \mathrm{CD} 11 \mathrm{~b}^{+}$Kupffer cells/macrophages and inflammatory responses [87]. LXR $\alpha$ plays a protective role against NASH by regulating cholesterol metabolism and immune responses. $\uparrow$, increase. 


\subsection{Hepatic Fibrosis}

HSCs from LXR $\alpha / \beta$-knockout mice contain more lipid droplets and demonstrate an increased expression of several fibrogenic genes, including Acta2 (the gene encoding $\alpha$-SMA) and Col1a1 [88]. Liver fibrosis that is induced by $\mathrm{CCl}_{4}$ treatment or methionine/choline-deficient diet is exacerbated, being marked by elevated plasma ALT levels and Col1a1 expression in LXR $\alpha / \beta$-knockout mice. Bone marrow transplantation of wild-type cells into LXR-null mice does not affect the fibrosis score, which indicates that the antifibrogenic effect of LXRs is not due to hematopoietic cells, such as BMDMs and lymphocytes. LXR $\alpha / \beta$-deficient HSCs store more cholesterol and retinyl esters and they have more retinoic acid-mediated profibrogenic action [98]. $\mathrm{CCl}_{4}$-treated $\mathrm{LXR} \alpha$-knockout mice also show the activation of LSECs, such as elevation of CD34 expression and capillarization [99]. Conversely, LXR ligand treatment suppresses capillarization through a mechanism that is mediated by Hedgehog signaling [89]. Genome-wide association studies have revealed that the patatin-like phospholipase domain-containing protein 3 (PNPLA3) I148M variant is associated with a higher risk of hepatic steatosis, fibrosis, and HCC [100]. PNPLA3 has lipase activity towards triglycerides in hepatocytes and retinyl esters in HSCs. Human HSCs expressing I148M PNPLA3 have decreased peroxisome proliferator-activated receptor $\gamma$ activity, which leads to impaired LXR signaling and cholesterol accumulation [101]. LXRs in HSCs and LSECs play a role in the regulation of liver fibrosis.

\subsection{Wilson Disease}

Wilson disease is caused by a genetic mutation of the ATP-dependent copper transporter protein ATP7B and it is characterized by hepatic copper accumulation and hepatitis. Microarray analysis shows that the expression of LXR-regulated lipid metabolism genes is impaired in the liver of patients with Wilson disease [90]. Protein levels of RXR, not $L X R \alpha$ or $L X R \beta$, are decreased in the liver of Atp7b-deficient mice, a model of Wilson disease. LXR ligand treatment of Atp7b-deficient mice does not change hepatic copper levels, but it reduces the expression of pro-inflammatory and profibrogenic genes and attenuates liver injury.

\section{Concluding Remarks}

LXRs are important regulators of cholesterol homeostasis and they have been investigated as promising therapeutic targets in the treatment of hypercholesterolemia and atherosclerosis. Impaired hepatic cholesterol metabolism is strongly associated with the pathogenesis and progression of HCD- and HFCD-induced liver diseases. LXR ligands are also candidate treatments for western diet-related liver diseases, such as NASH. LXRs are expressed not only in hepatocyte, but also in nonparenchymal cells, such as Kupffer cells, BMDMs, HSCs, and LSECs, and they play important roles in the regulation of inflammation, immune cell population, and activation through mechanisms that are related to and independent of their metabolic action. While many synthetic LXR agonists have been developed for the treatment of hypercholesterolemia and cancer, their clinical application is limited by hypertriglyceridemia and other adverse effects on the central nervous system [102,103]. Further studies are needed to develop cell- or function-selective ligands that target hepatic leukocytes, HSCs, and LSECs.

Author Contributions: Writing—original draft preparation, K.E.-U.; writing—review and editing, M.M.

Funding: This work was supported by JSPS KAKENHI Grant Numbers JP 25860248 and JP 16K19061 (to K.E.-U.), and Nihon University School of Medicine Toki Fund Research Grant (to K.E.-U.).

Acknowledgments: The authors thank Andrew I. Shulman for editorial assistance.

Conflicts of Interest: The authors declare no conflict of interest. 


\section{Abbreviations}

$\begin{array}{ll}\text { NAFLD } & \text { nonalcoholic fatty liver diseases } \\ \text { NASH } & \text { nonalcoholic steatohepatitis } \\ \text { LXR } & \text { liver X receptor } \\ \text { HSC } & \text { hepatic stellate cell } \\ \text { LSEC } & \text { liver sinusoidal endothelial cell } \\ \text { BMDM } & \text { bone marrow-derived macrophage } \\ \text { NK } & \text { natural killer } \\ \text { NKT } & \text { natural killer T } \\ \text { TLR } & \text { Toll-like receptor } \\ \text { TREM2 } & \text { triggered receptor expressed on myeloid cells 2 } \\ \text { MerTK } & \text { Mer receptor tyrosine kinase } \\ \alpha-S M A & \alpha \text {-smooth muscle actin } \\ \text { Col1a1 } & \text { collagen } \alpha 1 \text { (I) } \\ \text { HCC } & \text { hepatocellular carcinoma } \\ \alpha-G a l C e r & \alpha \text {-galactosylceramide } \\ \text { IL } & \text { interleukin } \\ \text { iNKT } & \text { invariant natural killer T } \\ \text { CXCR6 } & \text { C-X-C motif chemokine receptor 6 } \\ \text { HCD } & \text { high-cholesterol diet } \\ \text { HFCD } & \text { high-fat and high-cholesterol diet } \\ \text { HFD } & \text { high-fat diet } \\ \text { LPS } & \text { lipopolysaccharide } \\ \text { BDL } & \text { bile duct ligation } \\ \text { CCl } & \text { carbon tetrachloride } \\ \text { MNC } & \text { mononuclear cell } \\ \text { RXR } & \text { retinoid X receptor } \\ \text { ABC } & \text { ATP-binding cassette } \\ \text { CCL } & \text { C-C chemokine ligand } \\ \text { TNF } & \text { tumor necrosis factor } \\ \text { PNPLA3 } & \text { patatin-like phospholipase domain-containing } \\ & \text { protein 3 } \\ & \end{array}$

\section{References}

1. Ioannou, G.N. The role of cholesterol in the pathogenesis of nash. Trends Endocrinol. Metab. 2016, $27,84-95$. [CrossRef]

2. Min, H.K.; Kapoor, A.; Fuchs, M.; Mirshahi, F.; Zhou, H.; Maher, J.; Kellum, J.; Warnick, R.; Contos, M.J.; Sanyal, A.J. Increased hepatic synthesis and dysregulation of cholesterol metabolism is associated with the severity of nonalcoholic fatty liver disease. Cell Metab. 2012, 15, 665-674. [CrossRef] [PubMed]

3. Wang, B.; Tontonoz, P. Liver X receptors in lipid signalling and membrane homeostasis. Nat. Rev. Endocrinol. 2018, 14, 452-463. [CrossRef] [PubMed]

4. Makishima, M. Nuclear receptors as targets for drug development: Regulation of cholesterol and bile acid metabolism by nuclear receptors. J. Pharmacol. Sci. 2005, 97, 177-183. [CrossRef] [PubMed]

5. Raselli, T.; Hearn, T.; Wyss, A.; Atrott, K.; Peter, A.; Frey-Wagner, I.; Spalinger, M.R.; Maggio, E.M.; Sailer, A.W.; Schmitt, J.; et al. Elevated oxysterol levels in human and mouse livers reflect nonalcoholic steatohepatitis. J. Lipid Res. 2019, 60, 1270-1283. [CrossRef] [PubMed]

6. Alberti, S.; Schuster, G.; Parini, P.; Feltkamp, D.; Diczfalusy, U.; Rudling, M.; Angelin, B.; Bjorkhem, I.; Pettersson, S.; Gustafsson, J.A. Hepatic cholesterol metabolism and resistance to dietary cholesterol in LXRß-deficient mice. J. Clin. Invest. 2001, 107, 565-573. [CrossRef] [PubMed]

7. Racanelli, V.; Rehermann, B. The liver as an immunological organ. Hepatology 2006, 43, S54-S62. [CrossRef] [PubMed]

8. Gao, B.; Jeong, W.I.; Tian, Z. Liver: An organ with predominant innate immunity. Hepatology 2008, 47, 729-736. [CrossRef] [PubMed] 
9. Heymann, F.; Tacke, F. Immunology in the liver - from homeostasis to disease. Nat. Rev. Gastroenterol. Hepatol. 2016, 13, 88-110. [CrossRef] [PubMed]

10. Hashimoto, D.; Chow, A.; Noizat, C.; Teo, P.; Beasley, M.B.; Leboeuf, M.; Becker, C.D.; See, P.; Price, J.; Lucas, D.; et al. Tissue-resident macrophages self-maintain locally throughout adult life with minimal contribution from circulating monocytes. Immunity 2013, 38, 792-804. [CrossRef] [PubMed]

11. Gomez Perdiguero, E.; Klapproth, K.; Schulz, C.; Busch, K.; Azzoni, E.; Crozet, L.; Garner, H.; Trouillet, C.; de Bruijn, M.F.; Geissmann, F.; et al. Tissue-resident macrophages originate from yolk-sac-derived erythro-myeloid progenitors. Nature 2015, 518, 547-551. [CrossRef] [PubMed]

12. MacParland, S.A.; Liu, J.C.; Ma, X.-Z.; Innes, B.T.; Bartczak, A.M.; Gage, B.K.; Manuel, J.; Khuu, N.; Echeverri, J.; Linares, I.; et al. Single cell rna sequencing of human liver reveals distinct intrahepatic macrophage populations. Nat. Commun. 2018, 9, 4383. [CrossRef] [PubMed]

13. Aizarani, N.; Saviano, A.; Sagar; Mailly, L.; Durand, S.; Herman, J.S.; Pessaux, P.; Baumert, T.F.; Grün, D. A human liver cell atlas reveals heterogeneity and epithelial progenitors. Nature 2019,572,199-204. [CrossRef] [PubMed]

14. Guillot, A.; Tacke, F. Liver macrophages: Old dogmas and new insights. Hepatol. Commun. 2019, 3, 730-743. [CrossRef] [PubMed]

15. Kinoshita, M.; Uchida, T.; Sato, A.; Nakashima, M.; Nakashima, H.; Shono, S.; Habu, Y.; Miyazaki, H.; Hiroi, S.; Seki, S. Characterization of two F4/80-positive Kupffer cell subsets by their function and phenotype in mice. J. Hepatol. 2010, 53, 903-910. [CrossRef] [PubMed]

16. Ikarashi, M.; Nakashima, H.; Kinoshita, M.; Sato, A.; Nakashima, M.; Miyazaki, H.; Nishiyama, K.; Yamamoto, J.; Seki, S. Distinct development and functions of resident and recruited liver Kupffer cells/macrophages. J. Leukoc. Biol. 2013, 94, 1325-1336. [CrossRef] [PubMed]

17. Nishiyama, K.; Nakashima, H.; Ikarashi, M.; Kinoshita, M.; Nakashima, M.; Aosasa, S.; Seki, S.; Yamamoto, J. Mouse $\mathrm{CD} 11 \mathrm{~b}^{+}$Kupffer cells recruited from bone marrow accelerate liver regeneration after partial hepatectomy. PLoS ONE 2015, 10, e0136774. [CrossRef] [PubMed]

18. Zamara, E.; Galastri, S.; Aleffi, S.; Petrai, I.; Aragno, M.; Mastrocola, R.; Novo, E.; Bertolani, C.; Milani, S.; Vizzutti, F.; et al. Prevention of severe toxic liver injury and oxidative stress in MCP-1-deficient mice. J. Hepatol. 2007, 46, 230-238. [CrossRef]

19. Miura, K.; Yang, L.; van Rooijen, N.; Ohnishi, H.; Seki, E. Hepatic recruitment of macrophages promotes nonalcoholic steatohepatitis through CCR2. Am. J. Physiol. Gastrointest. Liver Physiol. 2012, 302, G1310-G1321. [CrossRef]

20. David, B.A.; Rezende, R.M.; Antunes, M.M.; Santos, M.M.; Freitas Lopes, M.A.; Diniz, A.B.; Sousa Pereira, R.V.; Marchesi, S.C.; Alvarenga, D.M.; Nakagaki, B.N.; et al. Combination of mass cytometry and imaging analysis reveals origin, location, and functional repopulation of liver myeloid cells in mice. Gastroenterology 2016, 151, 1176-1191. [CrossRef]

21. Krenkel, O.; Hundertmark, J.; Abdallah, A.T.; Kohlhepp, M.; Puengel, T.; Roth, T.; Branco, D.P.P.; Mossanen, J.C.; Luedde, T.; Trautwein, C.; et al. Myeloid cells in liver and bone marrow acquire a functionally distinct inflammatory phenotype during obesity-related steatohepatitis. Gut 2019. [CrossRef] [PubMed]

22. Colonna, M. Trems in the immune system and beyond. Nat. Rev. Immunol. 2003, 3, 445-453. [CrossRef] [PubMed]

23. Wang, Y.; Cella, M.; Mallinson, K.; Ulrich, J.D.; Young, K.L.; Robinette, M.L.; Gilfillan, S.; Krishnan, G.M.; Sudhakar, S.; Zinselmeyer, B.H.; et al. TREM2 lipid sensing sustains the microglial response in an Alzheimer's disease model. Cell 2015, 160, 1061-1071. [CrossRef] [PubMed]

24. Jonsson, T.; Stefansson, H.; Steinberg, S.; Jonsdottir, I.; Jonsson, P.V.; Snaedal, J.; Bjornsson, S.; Huttenlocher, J.; Levey, A.I.; Lah, J.J.; et al. Variant of TREM2 associated with the risk of Alzheimer's disease. N. Engl. J. Med. 2013, 368, 107-116. [CrossRef] [PubMed]

25. Guerreiro, R.; Wojtas, A.; Bras, J.; Carrasquillo, M.; Rogaeva, E.; Majounie, E.; Cruchaga, C.; Sassi, C.; Kauwe, J.S.; Younkin, S.; et al. TREM2 variants in Alzheimer's disease. N. Engl. J. Med. 2013, 368, 117-127. [CrossRef] [PubMed]

26. Savage, J.C.; Jay, T.; Goduni, E.; Quigley, C.; Mariani, M.M.; Malm, T.; Ransohoff, R.M.; Lamb, B.T.; Landreth, G.E. Nuclear receptors license phagocytosis by Trem $2^{+}$myeloid cells in mouse models of alzheimer's disease. J. Neurosci. 2015, 35, 6532-6543. [CrossRef] [PubMed] 
27. A-Gonzalez, N.; Bensinger, S.J.; Hong, C.; Beceiro, S.; Bradley, M.N.; Zelcer, N.; Deniz, J.; Ramirez, C.; Diaz, M.; Gallardo, G.; et al. Apoptotic cells promote their own clearance and immune tolerance through activation of the nuclear receptor LXR. Immunity 2009, 31, 245-258. [CrossRef] [PubMed]

28. Cochain, C.; Vafadarnejad, E.; Arampatzi, P.; Pelisek, J.; Winkels, H.; Ley, K.; Wolf, D.; Saliba, A.E.; Zernecke, A. Single-cell RNA-seq reveals the transcriptional landscape and heterogeneity of aortic macrophages in murine atherosclerosis. Circ. Res. 2018, 122, 1661-1674. [CrossRef]

29. Jaitin, D.A.; Adlung, L.; Thaiss, C.A.; Weiner, A.; Li, B.; Descamps, H.; Lundgren, P.; Bleriot, C.; Liu, Z.; Deczkowska, A.; et al. Lipid-associated macrophages control metabolic homeostasis in a Trem2-dependent manner. Cell 2019, 178, 686-698.e14. [CrossRef]

30. Xiong, X.; Kuang, H.; Ansari, S.; Liu, T.; Gong, J.; Wang, S.; Zhao, X.Y.; Ji, Y.; Li, C.; Guo, L.; et al. Landscape of intercellular crosstalk in healthy and nash liver revealed by single-cell secretome gene analysis. Mol. Cell 2019, 75, 644-660. [CrossRef]

31. Krenkel, O.; Hundertmark, J.; Ritz, T.P.; Weiskirchen, R.; Tacke, F. Single cell RNA sequencing identifies subsets of hepatic stellate cells and myofibroblasts in liver fibrosis. Cells 2019, 8, 503. [CrossRef] [PubMed]

32. Seki, E.; Schwabe, R.F. Hepatic inflammation and fibrosis: Functional links and key pathways. Hepatology 2015, 61, 1066-1079. [CrossRef] [PubMed]

33. Maslak, E.; Gregorius, A.; Chlopicki, S. Liver sinusoidal endothelial cells (LSECs) function and NAFLD; no-based therapy targeted to the liver. Pharmacol. Rep. 2015, 67, 689-694. [CrossRef] [PubMed]

34. Poisson, J.; Lemoinne, S.; Boulanger, C.; Durand, F.; Moreau, R.; Valla, D.; Rautou, P.E. Liver sinusoidal endothelial cells: Physiology and role in liver diseases. J. Hepatol. 2017, 66, 212-227. [CrossRef] [PubMed]

35. Kawano, T.; Cui, J.Q.; Koezuka, Y.; Toura, I.; Kaneko, Y.; Motoki, K.; Ueno, H.; Nakagawa, R.; Sato, H.; Kondo, E.; et al. CD1d-restricted and TCR-mediated activation of $\mathrm{V}_{\alpha} 14$ NKT cells by glycosylceramides. Science 1997, 278, 1626-1629. [CrossRef]

36. Bendelac, A.; Savage, P.B.; Teyton, L. The biology of NKT cells. Annu. Rev. Immunol. 2007, 25, $297-336$. [CrossRef] [PubMed]

37. Takeda, K.; Hayakawa, Y.; Van Kaer, L.; Matsuda, H.; Yagita, H.; Okumura, K. Critical contribution of liver natural killer T cells to a murine model of hepatitis. Proc. Natl. Acad. Sci. USA 2000, 97, 5498-5503. [CrossRef]

38. Crowe, N.Y.; Coquet, J.M.; Berzins, S.P.; Kyparissoudis, K.; Keating, R.; Pellicci, D.G.; Hayakawa, Y.; Godfrey, D.I.; Smyth, M.J. Differential antitumor immunity mediated by NKT cell subsets in vivo. J. Exp. Med. 2005, 202, 1279-1288. [CrossRef]

39. Seki, S.; Nakashima, H.; Nakashima, M.; Kinoshita, M. Antitumor immunity produced by the liver Kupffer cells, NK cells, NKT cells, and CD8 ${ }^{+}$CD122 ${ }^{+}$T cells. Clin. Dev. Immunol. 2011, 2011, 868345. [CrossRef]

40. Nakashima, H.; Inui, T.; Habu, Y.; Kinoshita, M.; Nagao, S.; Kawaguchi, A.; Miura, S.; Shinomiya, N.; Yagita, H.; Seki, S. Activation of mouse natural killer T cells accelerates liver regeneration after partial hepatectomy. Gastroenterology 2006, 131, 1573-1583. [CrossRef]

41. Liew, P.X.; Lee, W.Y.; Kubes, P. iNKT cells orchestrate a switch from inflammation to resolution of sterile liver injury. Immunity 2017, 47, 752-765. [CrossRef] [PubMed]

42. Geissmann, F.; Cameron, T.O.; Sidobre, S.; Manlongat, N.; Kronenberg, M.; Briskin, M.J.; Dustin, M.L.; Littman, D.R. Intravascular immune surveillance by CXCR6 ${ }^{+}$NKT cells patrolling liver sinusoids. PLoS Biol. 2005, 3, e113. [CrossRef] [PubMed]

43. Mossanen, J.C.; Kohlhepp, M.; Wehr, A.; Krenkel, O.; Liepelt, A.; Roeth, A.A.; Mockel, D.; Heymann, F.; Lammers, T.; Gassler, N.; et al. CXCR6 inhibits hepatocarcinogenesis by promoting natural killer T- and $\mathrm{CD}^{+}$T-cell-dependent control of senescence. Gastroenterology 2019, 156, 1877-1889. [CrossRef] [PubMed]

44. Tall, A.R.; Yvan-Charvet, L. Cholesterol, inflammation and innate immunity. Nat. Rev. Immunol. 2015, 15, 104-116. [CrossRef] [PubMed]

45. Van Rooyen, D.M.; Larter, C.Z.; Haigh, W.G.; Yeh, M.M.; Ioannou, G.; Kuver, R.; Lee, S.P.; Teoh, N.C.; Farrell, G.C. Hepatic free cholesterol accumulates in obese, diabetic mice and causes nonalcoholic steatohepatitis. Gastroenterology 2011, 141, 1393-1403. [CrossRef] [PubMed]

46. Mridha, A.R.; Wree, A.; Robertson, A.A.B.; Yeh, M.M.; Johnson, C.D.; Van Rooyen, D.M.; Haczeyni, F.; Teoh, N.C.; Savard, C.; Ioannou, G.N.; et al. NLRP3 inflammasome blockade reduces liver inflammation and fibrosis in experimental NASH in mice. J. Hepatol. 2017, 66, 1037-1046. [CrossRef] 
47. Shono, S.; Habu, Y.; Nakashima, M.; Sato, A.; Nakashima, H.; Miyazaki, H.; Kinoshita, M.; Tsumatori, G.; Shinomiya, N.; Seki, S. The immunologic outcome of enhanced function of mouse liver lymphocytes and Kupffer cells by high-fat and high-cholesterol diet. Shock 2011, 36, 484-493. [CrossRef]

48. McGettigan, B.; McMahan, R.; Orlicky, D.; Burchill, M.; Danhorn, T.; Francis, P.; Cheng, L.L.; Golden-Mason, L.; Jakubzick, C.V.; Rosen, H.R. Dietary lipids differentially shape nonalcoholic steatohepatitis progression and the transcriptome of Kupffer cells and infiltrating macrophages. Hepatology 2019, 70, 67-83. [CrossRef]

49. Nakashima, H.; Ogawa, Y.; Shono, S.; Kinoshita, M.; Nakashima, M.; Sato, A.; Ikarashi, M.; Seki, S. Activation of $\mathrm{CD}_{11 \mathrm{~b}}{ }^{+}$Kupffer cells/macrophages as a common cause for exacerbation of TNF/Fas-ligand-dependent hepatitis in hypercholesterolemic mice. PLoS ONE 2013, 8, e49339. [CrossRef]

50. Ioannou, G.N.; Landis, C.S.; Jin, G.Y.; Haigh, W.G.; Farrell, G.C.; Kuver, R.; Lee, S.P.; Savard, C. Cholesterol crystals in hepatocyte lipid droplets are strongly associated with human nonalcoholic steatohepatitis. Hepatol. Commun. 2019, 3, 776-791. [CrossRef]

51. Teratani, T.; Tomita, K.; Suzuki, T.; Oshikawa, T.; Yokoyama, H.; Shimamura, K.; Tominaga, S.; Hiroi, S.; Irie, R.; Okada, Y.; et al. A high-cholesterol diet exacerbates liver fibrosis in mice via accumulation of free cholesterol in hepatic stellate cells. Gastroenterology 2012, 142, 152-164. [CrossRef] [PubMed]

52. Rockey, D.C.; Boyles, J.K.; Gabbiani, G.; Friedman, S.L. Rat hepatic lipocytes express smooth muscle actin upon activation in vivo and in culture. J. Submicrosc. Cytol. Pathol. 1992, 24, 193-203. [PubMed]

53. Tomita, K.; Teratani, T.; Suzuki, T.; Shimizu, M.; Sato, H.; Narimatsu, K.; Usui, S.; Furuhashi, H.; Kimura, A.; Nishiyama, K.; et al. Acyl-CoA:cholesterol acyltransferase 1 mediates liver fibrosis by regulating free cholesterol accumulation in hepatic stellate cells. J. Hepatol. 2014, 61, 98-106. [CrossRef]

54. Tsuchida, T.; Lee, Y.A.; Fujiwara, N.; Ybanez, M.; Allen, B.; Martins, S.; Fiel, M.I.; Goossens, N.; Chou, H.I.; Hoshida, Y.; et al. A simple diet- and chemical-induced murine nash model with rapid progression of steatohepatitis, fibrosis and liver cancer. J. Hepatol. 2018, 69, 385-395. [CrossRef] [PubMed]

55. Janowski, B.A.; Willy, P.J.; Devi, T.R.; Falck, J.R.; Mangelsdorf, D.J. An oxysterol signalling pathway mediated by the nuclear receptor LXR $\alpha$. Nature 1996, 383, 728-731. [CrossRef] [PubMed]

56. Janowski, B.A.; Grogan, M.J.; Jones, S.A.; Wisely, G.B.; Kliewer, S.A.; Corey, E.J.; Mangelsdorf, D.J. Structural requirements of ligands for the oxysterol liver X receptors $L X R \alpha$ and LXR $\beta$. Proc. Natl. Acad. Sci. USA 1999, 96, 266-271. [CrossRef]

57. Chen, W.; Chen, G.; Head, D.L.; Mangelsdorf, D.J.; Russell, D.W. Enzymatic reduction of oxysterols impairs LXR signaling in cultured cells and the livers of mice. Cell Metab. 2007, 5, 73-79. [CrossRef] [PubMed]

58. Yang, C.; Yu, L.; Li, W.; Xu, F.; Cohen, J.C.; Hobbs, H.H. Disruption of cholesterol homeostasis by plant sterols. J. Clin. Invest. 2004, 114, 813-822. [CrossRef] [PubMed]

59. Endo-Umeda, K.; Aoyama, A.; Shimizu, M.; Ishikawa, M.; Hashimoto, Y.; Yamada, S.; Makishima, M. $1 \alpha$-Hydroxy derivatives of 7-dehydrocholesterol are selective liver $\mathrm{X}$ receptor modulators. J. Steroid Biochem. Mol. Biol. 2017, 172, 136-148. [CrossRef]

60. Peet, D.J.; Turley, S.D.; Ma, W.; Janowski, B.A.; Lobaccaro, J.M.; Hammer, R.E.; Mangelsdorf, D.J. Cholesterol and bile acid metabolism are impaired in mice lacking the nuclear oxysterol receptor LXR $\alpha$. Cell 1998, 93, 693-704. [CrossRef]

61. Repa, J.J.; Berge, K.E.; Pomajzl, C.; Richardson, J.A.; Hobbs, H.; Mangelsdorf, D.J. Regulation of ATP-binding cassette sterol transporters ABCG5 and ABCG8 by the liver $X$ receptors $\alpha$ and $\beta$. J. Biol. Chem. 2002, 277, 18793-18800. [CrossRef] [PubMed]

62. Repa, J.J.; Turley, S.D.; Lobaccaro, J.A.; Medina, J.; Li, L.; Lustig, K.; Shan, B.; Heyman, R.A.; Dietschy, J.M.; Mangelsdorf, D.J. Regulation of absorption and ABC1-mediated efflux of cholesterol by RXR heterodimers. Science 2000, 289, 1524-1529. [CrossRef] [PubMed]

63. Costet, P.; Luo, Y.; Wang, N.; Tall, A.R. Sterol-dependent transactivation of the $A B C 1$ promoter by the liver $\mathrm{X}$ receptor/retinoid X receptor. J. Biol. Chem. 2000, 275, 28240-28245. [PubMed]

64. Joseph, S.B.; McKilligin, E.; Pei, L.; Watson, M.A.; Collins, A.R.; Laffitte, B.A.; Chen, M.; Noh, G.; Goodman, J.; Hagger, G.N.; et al. Synthetic LXR ligand inhibits the development of atherosclerosis in mice. Proc. Natl. Acad. Sci. USA 2002, 99, 7604-7609. [CrossRef] [PubMed]

65. Zhang, Y.; Breevoort, S.R.; Angdisen, J.; Fu, M.; Schmidt, D.R.; Holmstrom, S.R.; Kliewer, S.A.; Mangelsdorf, D.J.; Schulman, I.G. Liver LXR $\alpha$ expression is crucial for whole body cholesterol homeostasis and reverse cholesterol transport in mice. J. Clin. Investig. 2012, 122, 1688-1699. [CrossRef] [PubMed] 
66. Tangirala, R.K.; Bischoff, E.D.; Joseph, S.B.; Wagner, B.L.; Walczak, R.; Laffitte, B.A.; Daige, C.L.; Thomas, D.; Heyman, R.A.; Mangelsdorf, D.J.; et al. Identification of macrophage liver X receptors as inhibitors of atherosclerosis. Proc. Natl. Acad. Sci. USA 2002, 99, 11896-11901. [CrossRef] [PubMed]

67. Joseph, S.B.; Castrillo, A.; Laffitte, B.A.; Mangelsdorf, D.J.; Tontonoz, P. Reciprocal regulation of inflammation and lipid metabolism by liver X receptors. Nat. Med. 2003, 9, 213-219. [CrossRef]

68. Ghisletti, S.; Huang, W.; Ogawa, S.; Pascual, G.; Lin, M.E.; Willson, T.M.; Rosenfeld, M.G.; Glass, C.K. Parallel sumoylation-dependent pathways mediate gene- and signal-specific transrepression by LXRs and PPAR $\gamma$. Mol. Cell 2007, 25, 57-70. [CrossRef]

69. Venteclef, N.; Jakobsson, T.; Ehrlund, A.; Damdimopoulos, A.; Mikkonen, L.; Ellis, E.; Nilsson, L.M.; Parini, P.; Janne, O.A.; Gustafsson, J.A.; et al. GPS2-dependent corepressor/SUMO pathways govern anti-inflammatory actions of LRH-1 and LXR $\beta$ in the hepatic acute phase response. Genes Dev. 2010, 24, 381-395. [CrossRef]

70. Ito, A.; Hong, C.; Rong, X.; Zhu, X.; Tarling, E.J.; Hedde, P.N.; Gratton, E.; Parks, J.; Tontonoz, P. LXRs link metabolism to inflammation through ABCA1-dependent regulation of membrane composition and tlr signaling. eLife 2015, 4, e08009. [CrossRef]

71. Thomas, D.G.; Doran, A.C.; Fotakis, P.; Westerterp, M.; Antonson, P.; Jiang, H.; Jiang, X.-C.; Gustafsson, J.-Å.; Tabas, I.; Tall, A.R. LXR suppresses inflammatory gene expression and neutrophil migration through cis-repression and cholesterol efflux. Cell Rep. 2018, 25, 3774-3785.e3774. [CrossRef]

72. Spann, N.J.; Garmire, L.X.; McDonald, J.G.; Myers, D.S.; Milne, S.B.; Shibata, N.; Reichart, D.; Fox, J.N.; Shaked, I.; Heudobler, D.; et al. Regulated accumulation of desmosterol integrates macrophage lipid metabolism and inflammatory responses. Cell 2012, 151, 138-152. [CrossRef] [PubMed]

73. Ramon-Vazquez, A.; de la Rosa, J.V.; Tabraue, C.; Lopez, F.; Diaz-Chico, B.N.; Bosca, L.; Tontonoz, P.; Alemany, S.; Castrillo, A. Common and differential transcriptional actions of nuclear receptors liver $\mathrm{X}$ receptors $\alpha$ and $\beta$ in macrophages. Mol. Cell. Biol. 2019, 39, e00376-18. [CrossRef] [PubMed]

74. Beceiro, S.; Pap, A.; Czimmerer, Z.; Sallam, T.; Guillen, J.A.; Gallardo, G.; Hong, C.; Noelia, A.; Tabraue, C.; Diaz, M.; et al. Liver $X$ receptor nuclear receptors are transcriptional regulators of dendritic cell chemotaxis. Mol. Cell. Biol. 2018, 38. [CrossRef] [PubMed]

75. Villablanca, E.J.; Raccosta, L.; Zhou, D.; Fontana, R.; Maggioni, D.; Negro, A.; Sanvito, F.; Ponzoni, M.; Valentinis, B.; Bregni, M.; et al. Tumor-mediated liver $X$ receptor- $\alpha$ activation inhibits CC chemokine receptor-7 expression on dendritic cells and dampens antitumor responses. Nat. Med. 2010, 16, 98-105. [CrossRef]

76. Ma, X.; Bi, E.; Huang, C.; Lu, Y.; Xue, G.; Guo, X.; Wang, A.; Yang, M.; Qian, J.; Dong, C.; et al. Cholesterol negatively regulates IL-9-producing $\mathrm{CD} 8^{+} \mathrm{T}$ cell differentiation and antitumor activity. J. Exp. Med. 2018, 215, 1555-1569. [CrossRef] [PubMed]

77. Tavazoie, M.F.; Pollack, I.; Tanqueco, R.; Ostendorf, B.N.; Reis, B.S.; Gonsalves, F.C.; Kurth, I.; Andreu-Agullo, C.; Derbyshire, M.L.; Posada, J.; et al. LXR/ApoE activation restricts innate immune suppression in cancer. Cell 2018, 172, 825-840. [CrossRef]

78. Herold, M.; Breuer, J.; Hucke, S.; Knolle, P.; Schwab, N.; Wiendl, H.; Klotz, L. Liver X receptor activation promotes differentiation of regulatory t cells. PLoS ONE 2017, 12, e0184985. [CrossRef]

79. Wang, Y.Y.; Dahle, M.K.; Agren, J.; Myhre, A.E.; Reinholt, F.P.; Foster, S.J.; Collins, J.L.; Thiemermann, C.; Aasen, A.O.; Wang, J.E. Activation of the liver $\mathrm{X}$ receptor protects against hepatic injury in endotoxemia by suppressing Kupffer cell activation. Shock 2006, 25, 141-146. [CrossRef]

80. Endo-Umeda, K.; Nakashima, H.; Komine-Aizawa, S.; Umeda, N.; Seki, S.; Makishima, M. Liver X receptors regulate hepatic F4/80 ${ }^{+} \mathrm{CD}_{11} \mathrm{~b}^{+}$Kupffer cells/macrophages and innate immune responses in mice. Sci. Rep. 2018, 8, 9281. [CrossRef]

81. Yang, C.Y.; Chen, J.B.; Tsai, T.F.; Tsai, Y.C.; Tsai, C.Y.; Liang, P.H.; Hsu, T.L.; Wu, C.Y.; Netea, M.G.; Wong, C.H.; et al. CLEC4F is an inducible c-type lectin in F4/80-positive cells and is involved in alpha-galactosylceramide presentation in liver. PLoS ONE 2013, 8, e65070. [CrossRef] [PubMed]

82. Lavin, Y.; Winter, D.; Blecher-Gonen, R.; David, E.; Keren-Shaul, H.; Merad, M.; Jung, S.; Amit, I. Tissue-resident macrophage enhancer landscapes are shaped by the local microenvironment. Cell 2014, 159, 1312-1326. [CrossRef] [PubMed]

83. Scott, C.L.; T'Jonck, W.; Martens, L.; Todorov, H.; Sichien, D.; Soen, B.; Bonnardel, J.; De Prijck, S.; Vandamme, N.; Cannoodt, R.; et al. The transcription factor ZEB2 is required to maintain the tissue-specific identities of macrophages. Immunity 2018, 49, 312-325. [CrossRef] [PubMed] 
84. Wang, Y.Y.; Dahle, M.K.; Steffensen, K.R.; Reinholt, F.P.; Collins, J.L.; Thiemermann, C.; Aasen, A.O.; Gustafsson, J.A.; Wang, J.E. Liver X receptor agonist GW3965 dose-dependently regulates LPS-mediated liver injury and modulates posttranscriptional TNF- $\alpha$ production and p38 mitogen-activated protein kinase activation in liver macrophages. Shock 2009, 32, 548-553. [CrossRef] [PubMed]

85. Liu, Y.; Han, X.; Bian, Z.; Peng, Y.; You, Z.; Wang, Q.; Chen, X.; Qiu, D.; Ma, X. Activation of liver X receptors attenuates endotoxin-induced liver injury in mice with nonalcoholic fatty liver disease. Dig. Dis. Sci. 2012, 57, 390-398. [CrossRef] [PubMed]

86. Miao, C.M.; He, K.; Li, P.Z.; Liu, Z.J.; Zhu, X.W.; Ou, Z.B.; Ruan, X.Z.; Gong, J.P.; Liu, C.A. LXR $\alpha$ represses LPS-induced inflammatory responses by competing with IRF3 for GRIP1 in Kupffer cells. Int. Immunopharmacol. 2016, 35, 272-279. [CrossRef] [PubMed]

87. Endo-Umeda, K.; Nakashima, H.; Umeda, N.; Seki, S.; Makishima, M. Dysregulation of Kupffer cells/macrophages and natural killer T cells in steatohepatitis in $\mathrm{LXR} \alpha$ knockout male mice. Endocrinology 2018, 159, 1419-1432. [CrossRef] [PubMed]

88. Beaven, S.W.; Wroblewski, K.; Wang, J.; Hong, C.; Bensinger, S.; Tsukamoto, H.; Tontonoz, P. Liver X receptor signaling is a determinant of stellate cell activation and susceptibility to fibrotic liver disease. Gastroenterology 2011, 140, 1052-1062. [CrossRef]

89. Xing, Y.; Zhao, T.; Gao, X.; Wu, Y. Liver X receptor $\alpha$ is essential for the capillarization of liver sinusoidal endothelial cells in liver injury. Sci. Rep. 2016, 6, 21309. [CrossRef]

90. Hamilton, J.P.; Koganti, L.; Muchenditsi, A.; Pendyala, V.S.; Huso, D.; Hankin, J.; Murphy, R.C.; Huster, D.; Merle, U.; Mangels, C.; et al. Activation of liver X receptor/retinoid X receptor pathway ameliorates liver disease in $A t p 7 B^{-/-}$(wilson disease) mice. Hepatology 2016, 63, 1828-1841. [CrossRef]

91. He, K.U.N.; Dai, Z.-Y.; Li, P.-Z.; Zhu, X.-W.; Gong, J.-P. Association between liver X receptor- $\alpha$ and neuron-derived orphan nuclear receptor-1 in Kupffer cells of C57BL/6 mice during inflammation. Mol. Med. Rep. 2015, 12, 6098-6104. [CrossRef] [PubMed]

92. Obstfeld, A.E.; Sugaru, E.; Thearle, M.; Francisco, A.M.; Gayet, C.; Ginsberg, H.N.; Ables, E.V.; Ferrante, A.W., Jr. C-C chemokine receptor 2 (CCR2) regulates the hepatic recruitment of myeloid cells that promote obesity-induced hepatic steatosis. Diabetes 2010, 59, 916-925. [CrossRef] [PubMed]

93. Schultz, J.R.; Tu, H.; Luk, A.; Repa, J.J.; Medina, J.C.; Li, L.; Schwendner, S.; Wang, S.; Thoolen, M.; Mangelsdorf, D.J.; et al. Role of LXRs in control of lipogenesis. Genes Dev. 2000, 14, 2831-2838. [CrossRef] [PubMed]

94. Repa, J.J.; Liang, G.; Ou, J.; Bashmakov, Y.; Lobaccaro, J.M.; Shimomura, I.; Shan, B.; Brown, M.S.; Goldstein, J.L.; Mangelsdorf, D.J. Regulation of mouse sterol regulatory element-binding protein-1c gene (SREBP-1c) by oxysterol receptors, LXR $\alpha$ and LXR $\beta$. Genes Dev. 2000, 14, 2819-2830. [CrossRef] [PubMed]

95. Bieghs, V.; Hendrikx, T.; van Gorp, P.J.; Verheyen, F.; Guichot, Y.D.; Walenbergh, S.M.; Jeurissen, M.L.; Gijbels, M.; Rensen, S.S.; Bast, A.; et al. The cholesterol derivative 27-hydroxycholesterol reduces steatohepatitis in mice. Gastroenterology 2013, 144, 167-178. [CrossRef] [PubMed]

96. Tang, T.; Sui, Y.; Lian, M.; Li, Z.; Hua, J. Pro-inflammatory activated Kupffer cells by lipids induce hepatic NKT cells deficiency through activation-induced cell death. PLoS ONE 2013, 8, e81949. [CrossRef] [PubMed]

97. Kremer, M.; Thomas, E.; Milton, R.J.; Perry, A.W.; van Rooijen, N.; Wheeler, M.D.; Zacks, S.; Fried, M.; Rippe, R.A.; Hines, I.N. Kupffer cell and interleukin-12-dependent loss of natural killer $\mathrm{T}$ cells in hepatosteatosis. Hepatology 2010, 51, 130-141. [CrossRef] [PubMed]

98. O'Mahony, F.; Wroblewski, K.; O’Byrne, S.M.; Jiang, H.; Clerkin, K.; Benhammou, J.; Blaner, W.S.; Beaven, S.W. Liver $\mathrm{X}$ receptors balance lipid stores in hepatic stellate cells through Rab18, a retinoid responsive lipid droplet protein. Hepatology 2015, 62, 615-626. [CrossRef]

99. Hammoutene, A.; Rautou, P.E. Role of liver sinusoidal endothelial cells in non-alcoholic fatty liver disease. J. Hepatol. 2019, 70, 1278-1291. [CrossRef]

100. Trepo, E.; Romeo, S.; Zucman-Rossi, J.; Nahon, P. PNPLA3 gene in liver diseases. J. Hepatol. 2016, 65, $399-412$. [CrossRef]

101. Bruschi, F.V.; Claudel, T.; Tardelli, M.; Starlinger, P.; Marra, F.; Trauner, M. PNPLA3 I148M variant impairs liver $\mathrm{X}$ receptor signaling and cholesterol homeostasis in human hepatic stellate cells. Hepatol. Commun. 2019, 3, 1191-1204. [CrossRef] [PubMed] 
102. Tice, C.M.; Noto, P.B.; Fan, K.Y.; Zhuang, L.; Lala, D.S.; Singh, S.B. The medicinal chemistry of liver X receptor (LXR) modulators. J. Med. Chem. 2014, 57, 7182-7205. [CrossRef] [PubMed]

103. Hong, C.; Tontonoz, P. Liver X receptors in lipid metabolism: Opportunities for drug discovery. Nat. Rev. Drug Discov. 2014, 13, 433-444. [CrossRef] [PubMed] 